\title{
The protective effects of lycopene on ischemia/reperfusion injury in rat hind limb muscle model
}

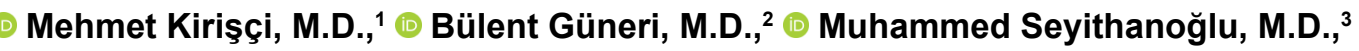

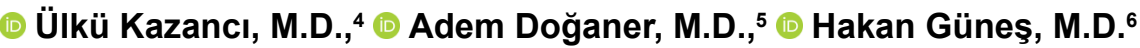

\begin{abstract}
${ }^{1}$ Department of Cardiovascular Surgery, Kahramanmaraş Sütçü İmam University Faculty of Medicine, Kahramanmaraş-Turkey
${ }^{2}$ Department of Orthopedics and Traumatology, Kahramanmaraş Sütçü İmam University Faculty of Medicine, Kahramanmaraş-Turkey

${ }^{3}$ Department of Medical Biochemistry, Kahramanmaraş Sütçü İmam University Faculty of Medicine, Kahramanmaraş-Turkey

${ }^{4}$ Department of Medical Pathology, Kahramanmaraş Sütçü İmam University Faculty of Medicine, Kahramanmaraş-Turkey

${ }^{5}$ Department of Biostatistics and Medical Informatics, Kahramanmaraş Sütçü İmam University Faculty of Medicine, Kahramanmaraş-Turkey

${ }^{6}$ Department of Cardiology, Kahramanmaraş Sütçü İmam University Faculty of Medicine, Kahramanmaraş-Turkey
\end{abstract}

\begin{abstract}
BACKGROUND: Acute ischemia/reperfusion (I/R) injury of skeletal muscle, an important mortality and morbidity cause, is associated with oxidative stress. Lycopene is a carotenoid pigment with potent antioxidant activity and is found in vegetables and fruits. This study aims to investigate the protective effects of lycopene against I/R injury in rat hind limb muscle model.

METHODS: Thirty-two Wistar-albino rats were randomly allocated to control, lycopene, I/R and I/R+lycopene groups. In lycopene and $\mathrm{I} / \mathrm{R}+$ lycopene groups, the rats received $10 \mathrm{mg} / \mathrm{kg} /$ day lycopene orally for 15 days before the experiment. Dissection around abdominal aorta at the infrarenal level was performed in all rats under general anesthesia. The aorta was clamped at the infrarenal level in the I/R and I/R+lycopene groups for two hours. Then, reperfusion was allowed for two hours in these groups. Samples were obtained from the hind limb muscles of rats after sacrifice for biochemical and histopathological analyses.

RESULTS: Serum and tissue malondialdehyde and ischemia-modified albumin levels were significantly lower in the $1 / R+l y c o p e n e$ group compared to I/R group $(\mathrm{p}<0.00 \mathrm{I})$. Serum glutathione peroxidase $(\mathrm{GSH}-\mathrm{Px}$ ) levels were significantly lower in the I/R group compared to those in control and I/R+lycopene groups $(p<0.05)$. Tissue GSH-Px levels were significantly lower in the $I / R$ group compared to the Lycopene group $(p=0.003$ ). Serum superoxide dismutase (SOD) levels were significantly lower in the $I / R$ group compared to three groups $(p<0.00 I)$. Tissue SOD levels were significantly lower in the I/R group compared to those in control and Lycopene groups $(p=0.005)$. Histopathological assessments revealed that inflammatory changes following I/R injury were significantly reduced in the $I /$ $\mathrm{R}+$ lycopene group.
\end{abstract}

CONCLUSION: The findings obtained in this study show lycopene's cytoprotective activity against I/R injury in rat skeletal muscle model.

Keywords: Antioxidants; ischemia; lycopene; reperfusion injury; tourniquets.

\section{INTRODUCTION}

Skeletal muscle tissue is relatively resistant to ischemia compared to other tissues. ${ }^{\left[{ }^{1]}\right.}$ Acute ischemia/reperfusion (I/R) injury of limb skeletal muscle, which arises from various mechanisms, is an important cause of mortality and morbidity. ${ }^{[2,3]}$
Thrombosis and embolism are the leading causes of acute limb ischemia. ${ }^{[4]}$ In addition, many events, such as abdominal aortic surgery, free-flap reconstruction procedures, trauma, surgical revascularization of limbs, and various orthopedic procedures with tourniquet use, may be associated with I/R injury. ${ }^{[5-8]}$ The skeletal muscle I/R injury initially leads to the

Cite this article as: Kirişçi M, Güneri B, Seyithanoğlu M, Kazancı Ü, Doğaner A, Güneş H. The protective effects of lycopene on ischemia/ reperfusion injury in rat hind limb muscle model. Ulus Travma Acil Cerrahi Derg 2020;26:351-360.

Address for correspondence: Bülent Güneri, M.D.

Kahramanmaraş Sütçü İmam Üniversitesi Tıp Fakültesi, Ortopedi ve Travmatoloji Anabilim Dalı, Kahramanmaraş, Turkey

Tel: +90 344 - 3003378 E-mail: bulentguneri@yahoo.com

Ulus Travma Acil Cerrahi Derg 2020;26(3):35I-360 DOI: 10.14744/tjtes.2020.8I456 Submitted: 12.06.20I9 Accepted: 30.03 .2020 Online: I4.05.2020

Copyright 2020 Turkish Association of Trauma and Emergency Surgery 
loss of contractile function of the muscles. Severe cases of $I / R$ injury may result in the loss of the limb or death. Reperfusion of tissues following a period of ischemia, which is essential for the viability of tissues, causes further damage by inducing both systemic and local inflammatory responses. Systemic inflammatory responses may lead to remote organ injury or multiple organ failure. ${ }^{[9]}$ Diffuse microvascular dysfunction and alterations in tissue barrier function may occur in association with inflammation. ${ }^{[10]}$

The skeletal muscle I/R injury is associated with oxidative stress as well. Biochemical reactions, activated by the skeletal muscle I/R injury, primarily lead to the loss in the supply of energy of the muscle resulting in endothelial dysfunction and neutrophil sequestration, which are followed by the formation of reactive oxygen species (ROS). ROS include free oxygen radicals, such as superoxide anion radicals and hydroxyl radicals. ROS attack lipids in the cell membrane and induce lipid peroxidation. Furthermore, ROS may affect cellular proteins, lipids, nucleic acids and other potentially sensitive substances. [11,12] Defensive antioxidant mechanisms, including superoxide dismutase (SOD) and glutathione peroxidase (GSH-Px), are activated in response to the formation of such noxious oxidative substances. These enzymes catalyze the transformation of ROS into less reactive species and protect the human body from the noxious effects of ROS and free radicals. Lipid peroxidation of cell membranes associated with I/R injury may lead to cell death. The alteration also occurs in the levels of malondialdehyde (MDA), an indicator of lipid peroxidation. [13] Ischemia-modified albumin (IMA) assay - also known as albumin cobalt binding assay - is another biomarker for tissue ischemia. In the $\mathrm{I} / \mathrm{R}$, acidosis and formation of free oxygen radicals may induce changes in binding capacity of albumin for cobalt. ${ }^{[14]}$ Various treatment strategies and studies on antioxidant vitamins, bioflavonoids and medicinal products aim to reduce injury associated with I/R. ${ }^{[15,16]}$

Lycopene is a carotenoid pigment found in vegetables and fruits, particularly in tomatoes, watermelons, pink grapefruits and pink guavas. Among dietary carotenoids, lycopene is the most potent antioxidant, anti-cancer and anti-inflammatory agent. ${ }^{[17-19]}$ Furthermore, lycopene has a protective effect against skin apoptosis resulting from ultraviolet rays. ${ }^{[20]}$ Antiinflammatory and antioxidant activities of lycopene have been considered to be responsible for its beneficial effects. ${ }^{[21,22]}$ Lycopene has long since been safely taken through dietary sources, including vegetables and fruits. Studies in rats have failed to demonstrate any teratogenic effects of lycopene storage in the plasma, on the liver or any other tissues. ${ }^{[23,24]}$ In this study, we aimed to investigate the antioxidative activity of lycopene against I/R injury in skeletal muscles of the hind limbs in rats.

\section{MATERIALS AND METHODS}

A total of 32 adult male Wistar-albino rats, weighing 200-250 g, were used in this study. The rats were housed and main-

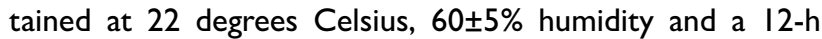
light-dark cycle with free access to food and water ad libitum. After this study was approved by the laboratory animals local ethics committee, this study was conducted in the animal experiments laboratory of the institution. All experimental procedures were performed according to the principles of laboratory animal care and use.

\section{Study Design and Experimental Procedures}

The rats were randomly allocated to four groups as follows: control group, lycopene (Lyc) group, I/R group, and I/R+lycopene (I/R+Lyc) group. Therefore, each group contained eight rats. In the Lyc group and I/R + Lyc group, the rats received $10 \mathrm{mg} / \mathrm{kg} /$ day lycopene (Redivivo Lyc 10\%; CWS/TG, Basel, Switzerland) with oral gavage for 15 days before the experimental procedure. All animals were anesthetized with ketamine hydrochloride (Ketalar 50 mg/kg i.m., ParkeDavis, Eczacıbaşı, Istanbul, Turkey). During the procedures, additional ketamine hydrochloride was applied intramuscularly as needed. The surgical procedures were performed to the rats laid in a supine position under a heating light. The skin was shaved, cleansed with antiseptic solutions, and a midline laparotomy was performed in each rat. Dissection around abdominal aorta at the infrarenal level was carried out in all rats. The abdominal aortae were clamped using atraumatic microvascular clamps (Micro DeBakey Bulldog Clamp, Biomedical Research Instruments, Malden, MA, USA) at the infrarenal level in the rats allocated to I/R and I/ $\mathrm{R}+$ Lyc groups, to induce hind limb ischemia. The distal flow was checked to ascertain the cessation of flow after clamping. The abdominal were closed using surgical towel clamps (Backhaus Towel Clamp, Bahadir Medical Instruments, Samsun, Turkey) after abdominal laparotomy, and dressings were used to maintain the temperature and hydration in these rats. After 120 minutes of ischemia, microvascular clamps were removed to allow reperfusion of hind limbs for 120 minutes. After the completion of reperfusion, the rats were sacrificed under anesthesia. In control and Lyc groups, rats were sacrificed after laparotomy without producing I/R injury. Blood and muscle tissue samples were obtained from all animals for biochemical and histopathological analyses.

\section{Biochemical Assessments}

All blood samples obtained from the rats at the end of the experimental procedures were centrifuged at $3000 \mathrm{rpm}$ for 10 minutes to separate the plasma. The plasma and muscle tissue samples were stored at -80 degrees Celsius until the time of analysis. The samples were thawed on the day of the analysis. The muscle tissues were homogenized in ice-cold 0.15 Molar (M) KCl (10\%, w/v). The tissue homogenates were centrifuged at 4 degrees Celsius for 10 minutes at $600 x g$ to separate crude fractions. Subsequently, supernatants were centrifuged for 20 minutes at 10,000xg to obtain the postmitochondrial fraction. 
GSH-Px, SOD, MDA, and IMA levels were measured as markers of oxidative stress. SOD and GSH-Px activities were measured in post-mitochondrial fractions of muscle tissue samples. MDA levels were measured in tissue homogenates.

Serum and tissue MDA levels were assayed using thiobarbituric acid according to the method of Buege and Aust. ${ }^{[25]}$ $0.5 \mathrm{~mL}$ distilled water was added to tubes containing $0.5 \mathrm{~mL}$ serum or tissue homogenate. $2 \mathrm{~mL}$ of Buege separator was added ( $15 \mathrm{w} / \mathrm{v}$ trichloroacetic acid, $0.375 \mathrm{w} / \mathrm{v} \%$ thiobarbituric acid and $0.25 \mathrm{~mol} / \mathrm{l}$ hydrochloric acid solution mixed in equal volumes) to the mixture. The tubes containing the mixture were boiled in a boiling water bath for 15 minutes. After cooling, the precipitate was centrifuged at $4000 \mathrm{rpm}$ for 10 minutes. The absorbance of the samples was determined by spectrophotometric method at $535 \mathrm{~nm}$.

The SOD activity was determined using Beyer and Fridovich's methodology. Accordingly, to obtain superoxide radicals reacting with 2-(4-iodophenyl)-3-(4-nitrophenol-s phenyltetrazolium chloride) to yield red formazan stain, xanthine and xanthine oxidase were used. Then, SOD activity was measured by the extent of inhibition of this reaction. ${ }^{[26]}$

The GSH-Px activity was measured using the method of Paglia and Valentine with cumenehydroperoxide as a substrate. In this method, GSH-Px activity was coupled to the oxidation of NADPH by glutathione reductase and the oxidation of NADPH was followed spectrophotometrically at 340 $\mathrm{nm}$ at 37 degrees Celsius. Results were calculated using the extinction coefficient $\left(6.22 \times 10^{3} / \mathrm{M} \mathrm{cm}\right) \cdot{ }^{[27]}$

Serum IMA levels were measured spectrophotometrically using the colorimetric method developed by Bar et al. ${ }^{[14]} 10 \mu \mathrm{l}$ of I $\mathrm{g} / \mathrm{l}$ cobalt chloride solution was added to $40 \mu \mathrm{l}$ of the serum, mixed and allowed to incubate for 10 minutes at room temperature. Then, $10 \mu \mathrm{l}$ of a $1.5 \mathrm{~g} / \mathrm{I}$ DTT solution was added and mixed. Incubated for two more minutes at room temperature, $200 \mu \mathrm{l}$ of a $9.0 \mathrm{~g} / \mathrm{l}$ solution of $\mathrm{NaCl}$ was added. Specimen blinds were similarly prepared without the addition of the DTT. The absorbance of the test mixtures was detected at $470 \mathrm{~nm}$. The results were evaluated in absorbance units.

\section{Histopathological Assessments}

The muscle tissues surgically excised for histopathological studies were immediately fixed in 10\% neutral formalin solution. Fixed tissue samples were embedded in paraffin and cut into serial sections with equal intervals. Each slide was stained with hematoxylin-eosin and examined and photographed under a light microscope (Nikon, Tokyo, Japan, 10x). Rat muscles were rated for histopathological assessment. A semi-quantitative histological analysis was performed to rate atrophy, peripheral location of nuclei, findings of perivascular inflammation or focal central muscle necrosis to define muscle breakdown using the light microscope: grade $0 /$ normal, grade I/mild, grade $2 /$ moderate, and grade $3 /$ severe.

\section{Statistical Analyses}

The normal distribution of the study data was evaluated using the Shapiro-Wilk test. The difference between the groups for variables with normal distribution was tested with oneway analysis of variance (ANOVA). For post-hoc pairwise comparisons, Tukey HSD, Tamhane T2, and Dunnett tests were used. Statistical parameters were expressed as mean \pm standard deviation. A p-value of less than 0.05 was considered significant. The results were also expressed in tables and figures. Data analysis was performed using IBM SPSS $V$ 22.0 (IMB Corporation, Armonk, New York, United States) software pack.

\section{RESULTS}

The analyses of muscle tissue and serum test results revealed statistically significant intergroup differences (Tables I and 2).

\section{Serum Biochemistry Results}

Significant intergroup differences were detected in the mean serum GSH-Px values; control group (136.56 \pm |4.77), Lyc group (I 24.27 \pm 35.48$)$, I/R group (105.63 I 3.39), and I/R+Lyc

Table I. The serum biochemical analyses

\begin{tabular}{|c|c|c|c|c|c|c|}
\hline & Control & Lycopene & $\mathbf{I} / \mathbf{R}$ & I/R+Lycopene & $\mathbf{F}$ & $\mathbf{p}$ \\
\hline & Mean $\pm S D$ & Mean $\pm S D$ & Mean $\pm S D$ & Mean $\pm S D$ & & \\
\hline GSH-Px nmol/mL & $\mid 36.56 \pm 14.77^{c}$ & $124.27 \pm 35.48$ & $105.63 \pm 13.39^{\mathrm{a}, \mathrm{d}}$ & $147.01 \pm 28.35^{c}$ & 3.463 & $0.033^{*}$ \\
\hline $\mathrm{MDA} \mathrm{nmol} / \mathrm{mL}$ & $23.53 \pm 4.22^{c}$ & $25.53 \pm 4.85^{c}$ & $54.57 \pm 13.62^{\mathrm{a}, \mathrm{b}, \mathrm{d}}$ & $28.33 \pm 3.77^{c}$ & 25.679 & $<0.001^{*}$ \\
\hline $\mathrm{SOD} U / \mathrm{mL}$ & $1.91 \pm 0.14^{c, d}$ & $1.83 \pm 0.15^{c, d}$ & $||. I \pm 0.05^{a, b, d}$ & $1.44 \pm 0.16^{\mathrm{a}, \mathrm{b}, \mathrm{c}}$ & 54.681 & $<0.00 I^{*}$ \\
\hline IMA abs/U & $0.44 \pm 0.02^{c}$ & $0.45 \pm 0.0 I^{c}$ & $0.50 \pm 0.03^{\mathrm{a}, \mathrm{b}, \mathrm{d}}$ & $0.42 \pm 0.04^{c}$ & 15.112 & $<0.00 I^{*}$ \\
\hline
\end{tabular}


Table 2. The muscle tissue biochemical analyses

\begin{tabular}{|c|c|c|c|c|c|c|}
\hline & Control & Lycopene & I/R & I/R+Lycopene & $\mathbf{F}$ & $\mathbf{p}$ \\
\hline & Mean士SD & Mean士SD & Mean士SD & Mean士SD & & \\
\hline GSH-Px nmol/mL & $159.16 \pm 49.97$ & $202.09 \pm 18.19^{c}$ & $123.03 \pm 19.18^{b}$ & $168.77 \pm 49.10$ & 6.038 & $0.003^{*}$ \\
\hline MDA nmol/mL & $92.25 \pm 6.74^{\mathrm{c}, \mathrm{d}}$ & $86.06 \pm 9.54^{c, d}$ & $126.94 \pm 18.22^{a, b, d}$ & $37.50 \pm 25.8 I^{a, b, c}$ & 38.239 & $0.001^{*}$ \\
\hline $\mathrm{SOD} \mathrm{U} / \mathrm{mL}$ & $35.69 \pm 12.03^{c}$ & $40.23 \pm 5.24^{c}$ & $23.86 \pm 4.25^{a, b}$ & $33.75 \pm 9.82$ & 5.325 & $0.005^{*}$ \\
\hline
\end{tabular}

group ( $47.01 \pm 28.35)$ (Fig. I). No significant differences were found between control and Lyc groups. When compared to $\mathrm{I} / \mathrm{R}+\mathrm{Lyc}$ group and control group, the mean serum GSH-Px levels were significantly lower in the I/R group $(p<0.05)$. The mean serum GSH-Px levels were significantly higher in the I/ $R+$ Lyc group compared to I/R group $(p<0.05)$.

Significant differences were detected between I/R group and other groups in the mean serum MDA values; control group (23.53 \pm 4.22$)$, Lyc group $(25.53 \pm 4.85)$, I/R group (54.57 \pm 13.62 ), and $1 / R+$ Lyc group (28.33 \pm 3.77$)$ (Fig. 2). The mean serum MDA values were statistically significantly higher in the I/R group compared to the other three groups $(p<0.001)$. No significant differences were found among the other three groups.

Significant intergroup differences were detected in the mean serum SOD values; control group (I.9I \pm 0.14$)$, Lyc group (I.83 \pm 0.15$)$, I/R group ( $I . I I \pm 0.05)$, and I/R+Lyc group (I.44 \pm 0.16$)$ (Fig. 3). No significant differences were found between control and Lyc groups. When compared to other groups, the mean serum SOD levels were significantly lower in the IR group $(p<0.00 I)$. The comparison between the I/ $\mathrm{R}+\mathrm{Lyc}$ and $\mathrm{I} / \mathrm{R}$ groups revealed that the mean serum SOD lev-

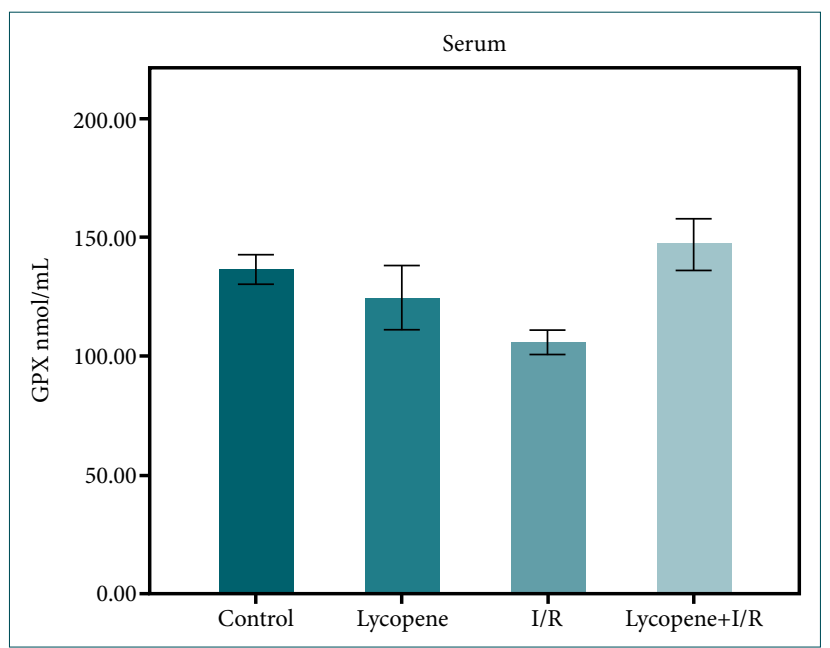

Figure 1. Intergroup comparisons of the serum glutathione peroxidase (GPX) levels. els were significantly higher in the $I / R+L y c$ group. The mean serum SOD levels were significantly lower in the $I / R+L y c$ group compared to control and Lyc groups $(p<0.00 \mathrm{I})$.

Intergroup comparisons of the mean serum IMA levels revealed significant differences between I/R group and other

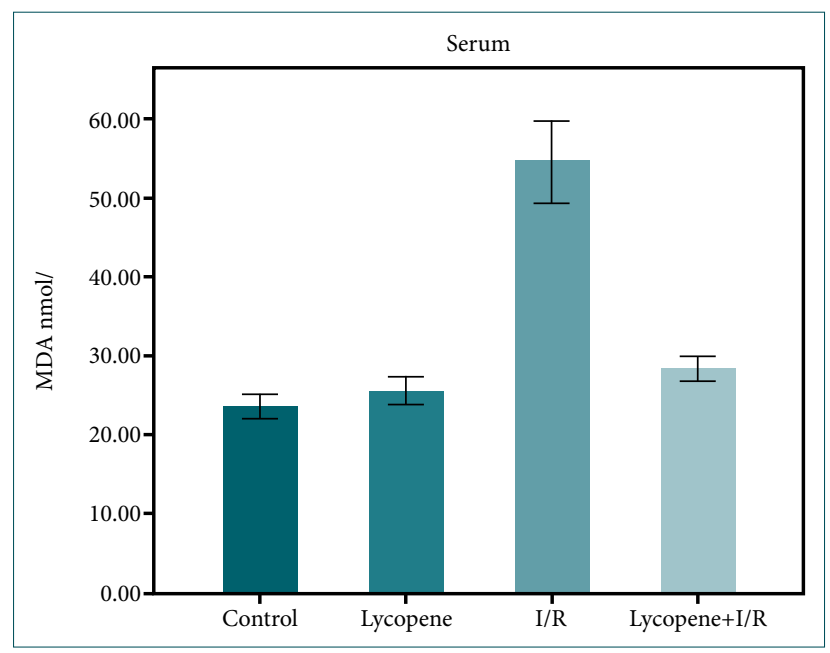

Figure 2. Intergroup comparisons of the serum malondialdehyde (MDA) levels.

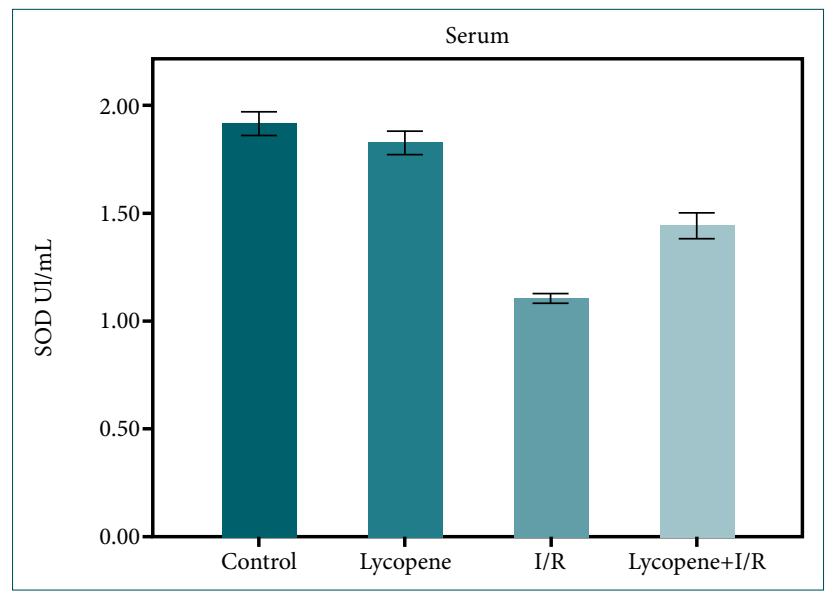

Figure 3. Intergroup comparisons of the serum superoxide dismutase (SOD) levels. 
groups; control group $(0.44 \pm 0.02)$, Lyc group $(0.45 \pm 0.01)$, $\mathrm{I} / \mathrm{R}$ group $(0.50 \pm 0.03)$, and $\mathrm{I} / \mathrm{R}+\mathrm{Lyc}$ group $(0.42 \pm 0.04)$ (Fig. 4). The mean serum IMA levels were statistically significantly higher in the $I / R$ group compared to the other three groups $(p<0.00 \mathrm{I})$. No significant differences were found among the other three groups.

\section{Muscle Tissue Biochemistry Results}

Intergroup comparisons of the mean muscle tissue GSH-Px levels revealed that the levels in the I/R group were statistically significant lower than those in Lyc group while no significant differences were found among other groups $(p<0.05)$; control group (159.16 \pm 49.97$)$, Lyc group (202.09 \pm 18.19), I/R group

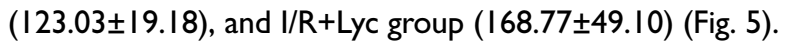

Intergroup comparisons of the mean muscle tissue MDA levels revealed significant differences; control group $(92.25 \pm 6.74)$, Lyc group (86.06 \pm 9.54$)$, I/R group (I26.94 \pm |8.22), and I/ $\mathrm{R}+$ Lyc group (37.50 $\pm 25.8 \mathrm{I}$ ) (Fig. 6). No significant differences were found between control and Lyc groups. The mean tissue MDA levels in the $I / R$ group were statistically significantly higher compared to the levels in other groups $(p<0.001)$. The

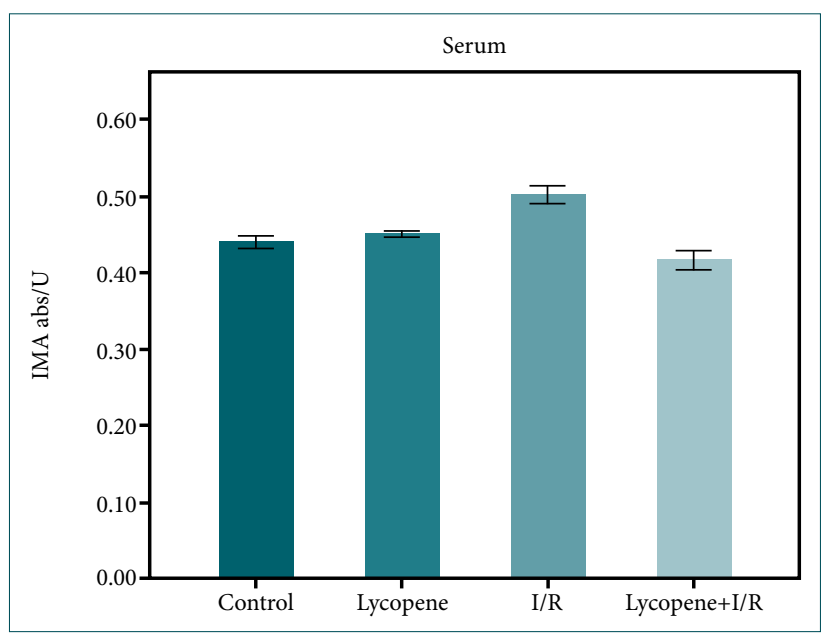

Figure 4. Intergroup comparisons of the serum (ischemia-modified albumin) IMA levels.

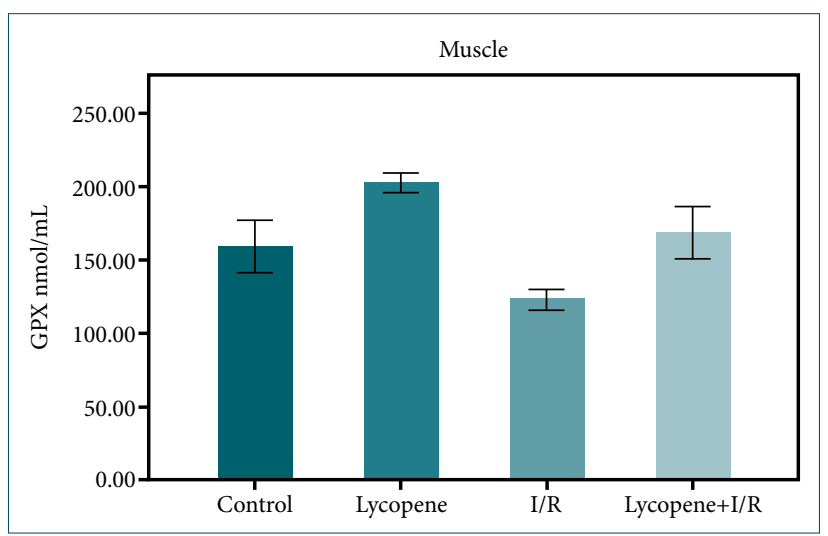

Figure 5. Intergroup comparisons of the muscle tissue glutathione peroxidase (GPX) levels. mean tissue MDA levels in the $I / R+L y c$ group were significantly lower compared to the levels in other groups $(p<0.001)$.

Intergroup comparisons of the mean muscle tissue SOD levels revealed that the mean enzyme levels were significantly lower in the $I / R$ group compared to control and Lyc groups $(p<0.00 I)$. The mean tissue SOD levels in the $I / R+$ Lyc groups did not significantly differ from the levels in other groups; control group (35.69 \pm 12.03$)$, Lyc group $(40.23 \pm 5.24)$, $1 / R$ group (23.86 \pm 4.25$)$, and $\mathrm{I} / \mathrm{R}+\mathrm{Lyc}$ group (33.75 \pm 9.82$)$ (Fig. 7).

\section{Histopathological Results}

Histopathological assessment of skeletal muscles was rated using the light microscope concerning atrophy, peripheral location of nuclei, signs of perivascular inflammation, and focal central muscle necrosis. Intergroup differences were assessed based on this rating (Table 3 ). In the histopathological assessment of skeletal muscles, atrophy was not observed in rats from control and Lyc groups while nuclei were peripherally located. Neither signs of perivascular inflammation nor focal central muscle necrosis were observed in these groups. Grade I atrophy was detected in the I/R group, while atrophy was significantly reduced in the $I / R+L y c$ group $(p<0.00 I)$. Nuclei were peripherally located in the samples from con-

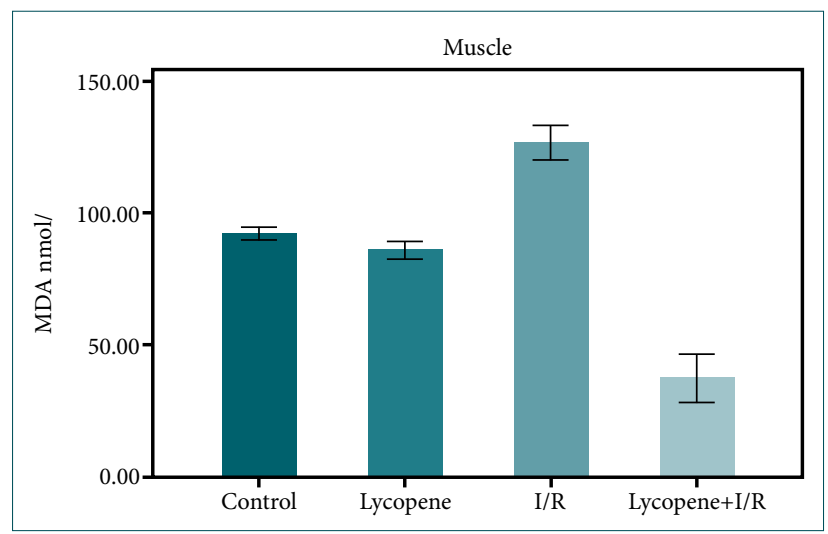

Figure 6. Intergroup comparisons of the muscle tissue malondialdehyde (MDA) levels.

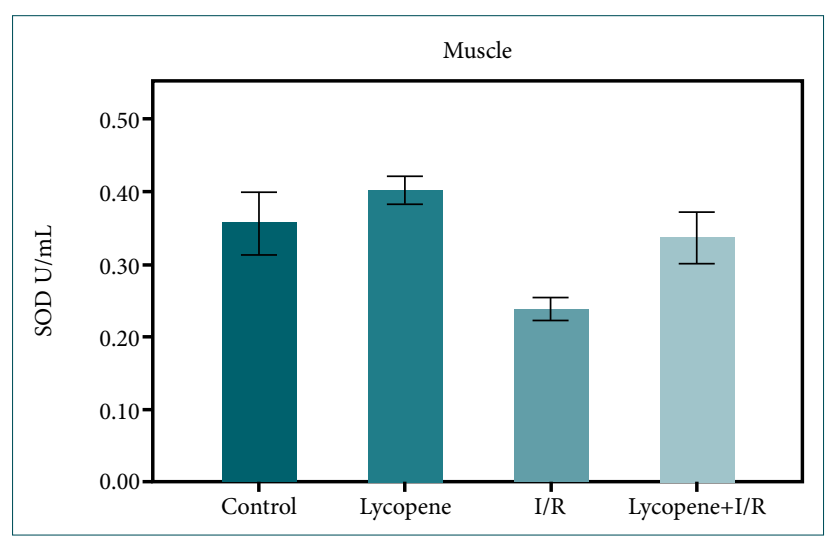

Figure 7. Intergroup comparisons of the muscle tissue superoxide dismutase (SOD) levels. 
Table 3. The intergroup comparisons regarding grading of the tissue specimens by histological evaluation

\begin{tabular}{|c|c|c|c|c|c|c|c|}
\hline $\begin{array}{l}\text { Histological findings } \\
\text { in tissue specimens }\end{array}$ & $\begin{array}{l}\text { Grading by } \\
\text { histological } \\
\text { evaluation }\end{array}$ & $\begin{array}{l}\text { Control } \\
\text { group } \\
(n=8)\end{array}$ & $\begin{array}{l}\text { I/R group } \\
\quad(n=8)\end{array}$ & $\begin{array}{l}\text { Lycopene } \\
\text { group } \\
(n=8)\end{array}$ & $\begin{array}{l}\text { I/R+Lycopene } \\
\text { group }(n=8)\end{array}$ & $\mathrm{X}^{2}$ & $\mathbf{p}$ \\
\hline \multirow[t]{4}{*}{ Atrophy } & Grade 0 & 8 & 0 & 7 & 7 & 28.486 & $<0.001^{*}$ \\
\hline & Grade I & 0 & 8 & I & I & & \\
\hline & Grade 2 & 0 & 0 & 0 & 0 & & \\
\hline & Grade 3 & 0 & 0 & 0 & 0 & & \\
\hline Peripherally located & Grade 0 & 0 & 0 & 0 & 0 & 22.154 & $<0.001^{*}$ \\
\hline \multirow[t]{3}{*}{ nuclei } & Grade I & 0 & 0 & 0 & 0 & & \\
\hline & Grade 2 & 0 & 6 & 0 & 0 & & \\
\hline & Grade 3 & 8 & 2 & 8 & 8 & & \\
\hline Signs of perivascular & Grade 0 & 8 & 0 & 8 & 4 & 33.778 & $<0.001^{*}$ \\
\hline \multirow[t]{3}{*}{ inflammation } & Grade I & 0 & 0 & 0 & 3 & & \\
\hline & Grade 2 & 0 & 4 & 0 & I & & \\
\hline & Grade 3 & 0 & 4 & 0 & 0 & & \\
\hline \multirow{4}{*}{$\begin{array}{l}\text { Focal central muscular } \\
\text { necrosis }\end{array}$} & Grade 0 & 8 & 0 & 6 & 2 & 28.667 & $0.001^{*}$ \\
\hline & Grade I & 0 & 4 & 2 & 6 & & \\
\hline & Grade 2 & 0 & 4 & 0 & 0 & & \\
\hline & Grade 3 & 0 & 0 & 0 & 0 & & \\
\hline
\end{tabular}

Exact test; $\alpha: 0.05$. "Statistically significant intergroup difference was detected in the distribution of variables. I/R: Ischemia/reperfusion.

trol, Lyc, and I/R+Lyc groups, while the peripheral location of nuclei was altered in the I/R group $(p<0.001)$. Perivascular infiltration was not observed in control and Lyc groups; however, the number of perivascular inflammatory cells was remarkable in the $I / R$ group $(p<0.00 I)$. Perivascular inflammation significantly reduced but persisted in the $I / R+L y c$ group compared to the control group. A moderate-intensity focal central muscular necrosis was observed in the I/R group. Focal central muscular necrosis significantly reduced in the $\mathrm{I} /$ $\mathrm{R}+$ Lyc group compared to the I/R group (Figs. 8-II).

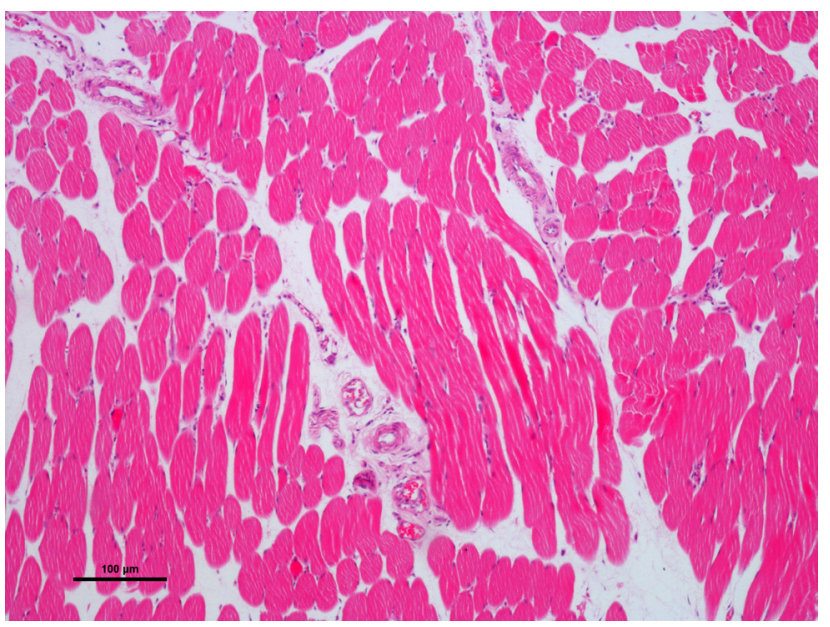

Figure 8. Histopathological assessment of the control group. Regular sarcoplasm and peripheral nuclei are seen in this tissue sample.

\section{DISCUSSION}

In oxidative stress, the balance between the antioxidant mechanism and free radicals in the cell and body system disappears. I/R injury of skeletal muscle, a condition of oxidative stress resulting from vascular or traumatic injuries, may cause a series of events, including severe cellular and organ dysfunctions. ${ }^{[28,29]} \mathrm{I} / \mathrm{R}$ injury induces biochemical events, which result in depletion of energy supplies of muscles, endothelial dysfunction, neutrophil sequestration and eventual ROS forma-

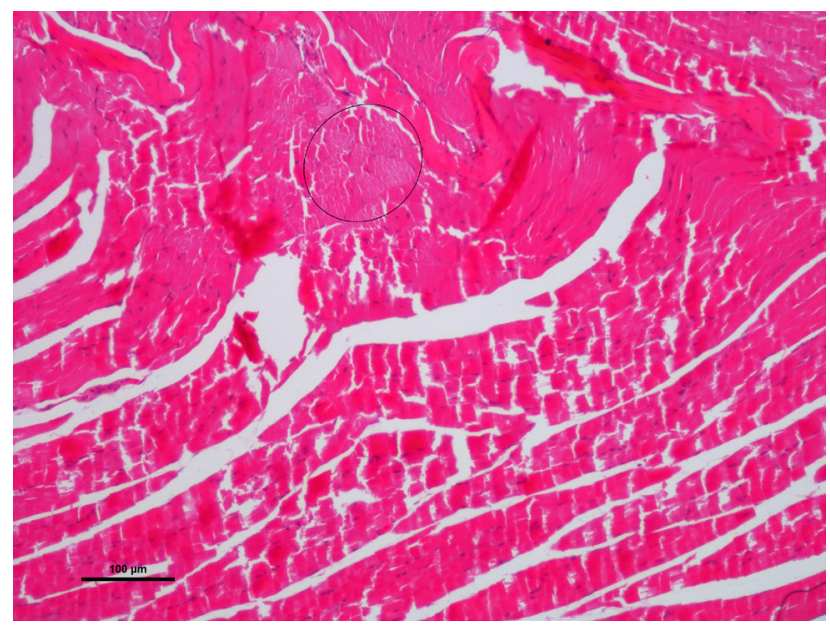

Figure 9. Histopathological assessment of the lycopene group. Regular sarcoplasm, peripheral nuclei and signs of mild atrophy (encircled) are seen in this tissue sample. 


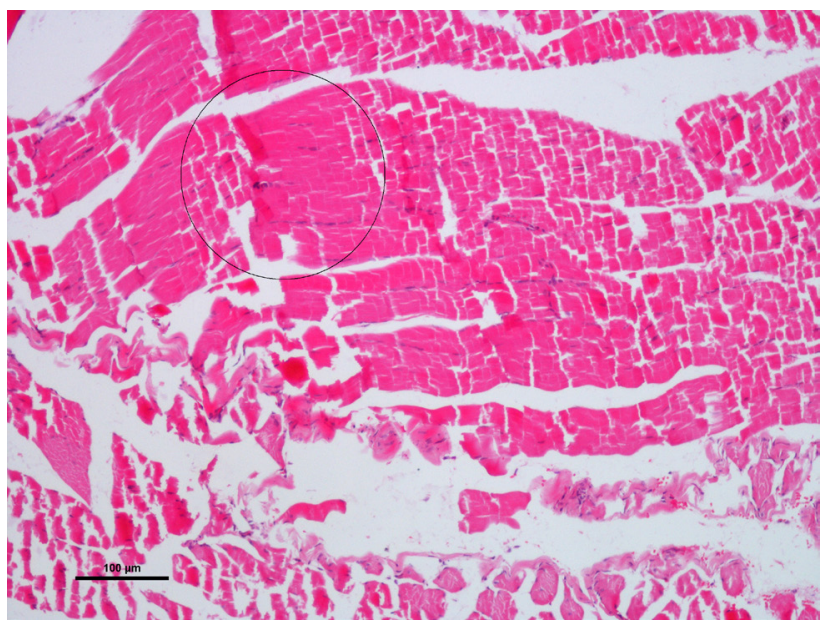

Figure 10. Histopathological assessment of the ischemia-reperfusion group. Focal central muscular necrosis and signs of mild atrophy (encircled) are seen in this tissue sample.

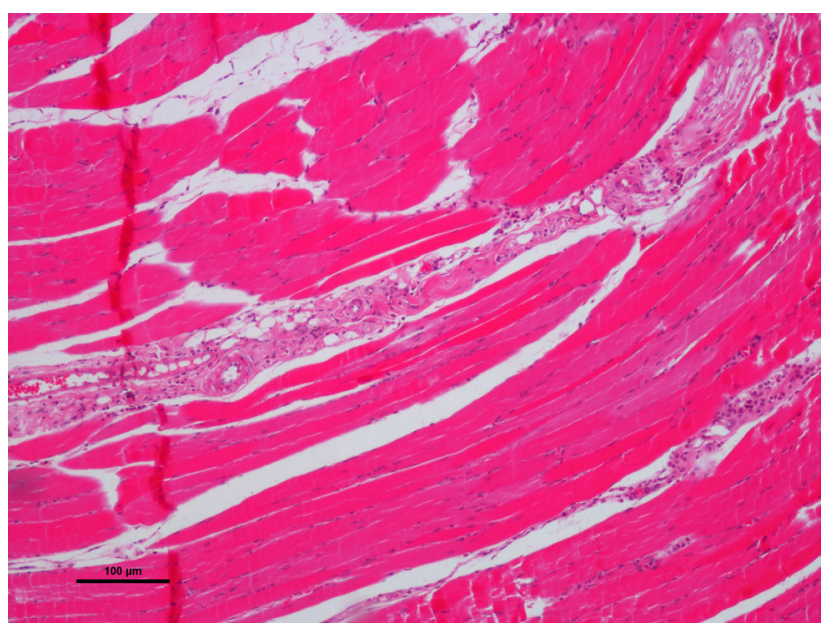

Figure 11. Histopathological assessment of the ischemia-reperfusion+lycopene group. Sparse necrosis is seen in this tissue sample.

tion. ${ }^{[1,12]}$ Granulocytes and macrophages, along with humoral factors, including complements and coagulation factors, contribute to the injury. ROS are potent oxidizing and reducing agents which damage cell membranes by lipid peroxidation and lead to the activation of neutrophils. ${ }^{[30]}$ These molecules have been considered to play an important role in the tissue damage associated with $I / R$ injury.

The entry of a high number of leukocytes into extracellular space immediately after reperfusion is particularly associated with the release of huge amounts of ROS, which is likely to overcome cellular antioxidant defenses. The frontline defenders battling against oxygen radicals include the enzymes SOD and GSH-Px. Various natural substances have been tested for restriction or prevention of ROS induced I/R injury. Elmali et al. ${ }^{[1]}$ studied the effects of resveratrol, a phytoalexin produced by several plants, in striated muscle of hind limb of 24 Sprague-Dawley rats regarding I/R injury. Their study included four groups all of which featured tourniquet applica- tion: two treatment groups (resveratrol in $0.5 \%$ ethyl alcohol administration before tourniquet release with four-hour and eight-hour reperfusion) and two control groups ( $0.5 \%$ ethyl alcohol administration before tourniquet release with fourhour and eight-hour reperfusion). The MDA levels, as well as polymorphonuclear leukocyte infiltration, edema, change in muscle fiber diameter and segmental necrosis, were less in treatment groups than those in control groups. Concerning these findings, the authors mentioned the protective effects of resveratrol against I/R injury in striated muscles following tourniquet application.

Ozyurt et al. ${ }^{[32]}$ investigated the preventive effects of caffeic acid phenethyl ester (CAPE), a component of propolis, on $\mathrm{I} / \mathrm{R}$ injury induced in rat hind limbs. Their study included four groups (sham, I/R, I/R+CAPE and I/R+vitamin E) in which rats were exposed to single-limb ischemia and reperfusion, each stage lasting two hours. CAPE and vitamin E were administered one hour after the onset of ischemia. The results of two treatment groups (I/R+CAPE and $I / R+v i t a m i n ~ E)$ indicated lower MDA and NO levels in plasma and muscle compared to I/R group. No difference was noted concerning muscle tissue SOD activity in three groups, but plasma SOD activity was greater in two treatment groups compared to I/R group. In view of these findings, the authors stressed the benefits of CAPE administration which had also been mentioned to be comparable to those of vitamin E.

Distinct from the aforementioned studies studying natural substances, Koca et al. ${ }^{[33]}$ investigated the effects of hyperbaric oxygen and ozone treatment before the induction of $I / R$ injury concerning oxidative/nitrosative stress. The authors reported an increase in tissue MDA levels, tissue SOD activity, serum nitrite-nitrate levels and decrease in tissue GSH-Px activity in the I/R group. Unlike I/R group, a decrease in MDA and nitrite-nitrate tissue levels and increase in tissue GSH-Px activity were detected in both I/R+hyperbaric oxygen and I/ $\mathrm{R}+$ ozone groups. SOD activity was found to be increased in the $I / R+o z o n e$ group while the change in the $I / R+$ hyperbaric oxygen group was insignificant. Tissue essays by inducible nitric oxide synthase staining demonstrated fewer changes in the $\mathrm{I} / \mathrm{R}+$ ozone and $\mathrm{I} / \mathrm{R}+$ hyperbaric oxygen groups compared to $I / R$ group. The results of this study indicated the protective features of hyperbaric oxygen and ozone treatment against $\mathrm{I} / \mathrm{R}$ injury in rat skeletal muscle.

Lycopene, a carotenoid compound abundantly found in red fruits, has potent antioxidative properties as well. It has been studied in various tissues other than skeletal muscle concerning I/R injury restriction or prevention. In a study of experimental renal I/R injury, Kaya et al. ${ }^{[34]}$ orally administered 100 $\mathrm{mg} / \mathrm{kg}$ of lycopene to rats six hours before the procedure. Both renal arteries were clamped for 45 minutes to create ischemia. After that, the clamps were removed and the kidneys were reperfused for six hours. Tissue and serum samples were collected to measure MDA, glutathione (GSH), urea 
(BUN) and creatinine. Based on the study results, a significant decrease was detected in BUN, MDA and creatinine levels while an increase in GSH levels was observed in the group receiving lycopene. The results from this study demonstrate that lycopene has protective effects on renal tissue against I/R injury.

In an experimental study conducted by Hua et al., ${ }^{[35]}$ spinal cord ischemia was induced by cyclooxygenase-2 (cox-2) suppression. Lycopene was administered for 14 days following cox-2 suppression. The reduction was observed in neuroinflammation and neuronal cell death in tissue and blood samples collected at the end of 14 days of treatment. Furthermore, Hua et al. demonstrated that increased cox-2, nuclear factor- $\kappa \mathrm{B}$, activated protein-I and reduced heme oxygenase-I levels, which were induced by spinal cord ischemia, could also be restored to normal by lycopene. Therefore, the relevant study indicated the neuroprotective activity of lycopene.

Bansal et al. ${ }^{[36]}$ administered lycopene to rats for 31 days at a dose of $1 \mathrm{mg} / \mathrm{kg}$ daily. Subsequently, they induced myocardial I/R by creating ischemia for 45 minutes and reperfusion for one hour in an experimental study. Serum samples were collected and MDA, SOD and GSH-Px levels were measured. MDA levels were found to be statistically significantly higher in the I/R group compared to the control group, while a statistically significant decline was observed in MDA levels in the group receiving lycopene. When compared to the control group, a statistically significant decline was observed in SOD and GSH-Px levels in the I/R group while a non-significant increase was detected in SOD levels and a statistically significant increase was detected in GSH-Px levels in the group receiving lycopene. Lower SOD and GSH-Px levels, detected following I/R, suggested that antioxidant enzyme activity had probably been inhibited due to intensive oxidative stress. When compared to I/R group, higher enzyme levels associated with the antioxidative effects of lycopene revealed its protective effects against oxidative stress.

In the $I / R+$ Lyc group of the present study, a significant decrease was observed in the serum and tissue MDA levels, as well as the serum IMA levels, compared to the I/R group, indicating significant increase due to overwhelming oxidative stress in the latter group and antioxidative effects of lycopene in the former group. The low mean levels of tissue MDA relative to the mean levels of serum MDA in the $I / R+L y c$ group can be explained with the likely superior potency of lycopene on hampering MDA formation in skeletal muscle compared to serum.

The mean tissue and serum levels of antioxidant enzymes (i.e., GSH-Px and SOD) utilized to measure oxidative stress were significantly suppressed in the I/R group. Besides, the mean serum levels of the antioxidant enzymes in the $\mathrm{I} / \mathrm{R}+\mathrm{Lyc}$ group were remarkably higher than those in the I/R group, an additional indicator of the protective effects of lycopene against $\mathrm{I} / \mathrm{R}$ injury. However, the mean tissue levels of the enzymes were relatively high in the $I / R+L y c$ group without statistical significance in comparison to the tissue levels in the I/R group. These differences regarding the comparisons of mean tissue and serum levels of antioxidant enzymes can be attributed to the duration of ischemia and reperfusion stages of this study (i.e., 120 minutes for each stage). Other explanations for the difference of the biochemical parameters between the muscle tissue and serum are the chain reaction nature of oxidative processes (i.e., one process can potentiate another) and the differences between the reactions of skeletal muscle and serum to the antioxidative effects of lycopene. ${ }^{[37]}$

Histopathological examination of the muscle tissue specimens by light microscopy reveals considerable tissue damage in the I/R group compared to I/R+Lyc group in which atrophy, perivascular inflammation, and focal central muscular necrosis were decreased while peripheral positioning of the nuclei was maintained. Concerning biochemical and histopathological findings of the present study, we suggest that dietary intake of lycopene can be beneficial to restrict or prevent the I/R injury of skeletal muscle and can thus enhance the healing following limb ischemia due to traumatic or vascular events or extensive surgical procedures with tourniquet use. These findings are in line with the studies which investigated the protective effects of lycopene against I/R injury of various tissues other than skeletal muscle.

Ischemia/reperfusion injury is a process involving multiple complex mechanisms and the outcomes of these injuries are quite debilitating or life-threatening. In the literature, there are studies demonstrating both anti-inflammatory and antioxidant activities of lycopene. ${ }^{[38-41]}$ To our knowledge, there is no previous animal study investigating the effects of lycopene on I/R injury of skeletal muscle. The results of the present study show the protective effects of lycopene on muscle tissue exposed to I/R injury and strongly support the claim that lycopene has antioxidative effects. However, antioxidative effects alone can hardly explain the protective effects of lycopene against skeletal muscle injury. Various mechanisms, including anti-inflammatory effects, may contribute to its protective activities.

\section{Conclusion}

The results of this study demonstrate the antioxidative and cytoprotective effects of lycopene against I/R injury of skeletal muscle. Since lycopene is a safe and potent antioxidative natural substance and is available for oral intake by diet or supplementation, its use before extensive limb surgeries, including tourniquet use as well as in cases with limb ischemia, seems favorable. Antioxidative effects alone can hardly explain the protective effects of lycopene against I/R induced skeletal muscle injury. Further studies may be required to gain deeper insight into the lycopene's mechanism of action before introducing lycopene into clinical use for restriction or prevention of the $\mathrm{I} / \mathrm{R}$ injuries. 
Ethics Committee Approval: Approved by the local ethics committee.

\section{Peer-review: Internally peer-reviewed.}

Authorship Contributions: Concept: M.K., B.G., H.G.; Design: M.K., B.G., H.G.; Supervision: B.G.; Fundings: M.K.; Materials: M.K., M.S., Ü.K.; Data: M.K., M.S., Ü.K., A.D.; Analysis: M.S., Ü.K., A.D.; Literature search: M.K., B.G.; Writing: M.K., B.G.; Critical revision: M.K., B.G.

\section{Conflict of Interest: None declared.}

Financial Disclosure: The authors declared that this study has received no financial support.

\section{REFERENCES}

1. Bushell AJ, Klenerman L, Taylor S, Davies H, Grierson I, Helliwell TR, et al. Ischaemic preconditioning of skeletal muscle. 1. Protection against the structural changes induced by ischaemia/reperfusion injury. J Bone Joint Surg Br 2002;84:1184-8. [CrossRef]

2. Blaisdell FW. The pathophysiology of skeletal muscle ischemia and the reperfusion syndrome: a review. Cardiovasc Surg 2002;10:620-30.

3. Avci G, Kadioglu H, Sehirli AO, Bozkurt S, Guclu O, Arslan E, et al. Curcumin protects against ischemia/reperfusion injury in rat skeletal muscle. J Surg Res 2012;172:e39-46. [CrossRef]

4. Earnshaw JJ. Demography and etiology of acute leg ischemia. Semin Vasc Surg 2001;14:86-92. [CrossRef]

5. Beyersdorf F, Unger A, Wildhirt A, Kretzer U, Deutschländer N, Krüger $\mathrm{S}$, et al. Studies of reperfusion injury in skeletal muscle: preserved cellular viability after extended periods of warm ischemia. J Cardiovasc Surg (Torino) 1991;32:664-76.

6. Lowrie AG, Berry MG, Kirkpatrick JJ, Lees VC, McGrouther DA. Arterial injuries at the elbow carry a high risk of muscle necrosis and warrant urgent revascularisation. Ann R Coll Surg Engl 2012;94:124-8. [CrossRef]

7. Sacks JM, Kuo YR, Horibe EK, Hautz T, Mohan K, Valerio IL, et al. An optimized dual-surgeon simultaneous orthotopic hind-limb allotransplantation model in rats. J Reconstr Microsurg 2012;28:69-75. [CrossRef]

8. Schmidt Y, Bannasch H, Eisenhardt SU. Ischemia-reperfusion injury leads to significant tissue damage in free flap surgery. Plast Reconstr Surg 2012;129:174e-6e. [CrossRef]

9. Oktar GL, Kirisci M, Dursun AD, Zor MH, Iriz E, Erer D, et al. Antioxidative effects of adrenomedullin and vascular endothelial growth factor on lung injury induced by skeletal muscle ischemia-reperfusion. Bratisl Lek Listy 2013;114:625-8. [CrossRef]

10. Eltzschig HK, Collard CD. Vascular ischaemia and reperfusion injury [published correction appears in Br Med Bull. 2005;73-74:139]. Br Med Bull 2004;70:71-86. [CrossRef]

11. Bulkley GB. Reactive oxygen metabolites and reperfusion injury: aberrant triggering of reticuloendothelial function. Lancet 1994;344:934-6.

12. Pattwell D, McArdle A, Griffiths RD, Jackson MJ. Measurement of free radical production by in vivo microdialysis during ischemia/reperfusion injury to skeletal muscle. Free Radic Biol Med 2001;30:979-85.

13. Ekinci Akdemir FN, Gülçin I, Karagöz B, Soslu R, Alwasel SH. A comparative study on the antioxidant effects of hesperidin and ellagic acid against skeletal muscle ischemia/reperfusion injury. J Enzyme Inhib Med Chem 2016;31:114-8. [CrossRef]

14. Bar-Or D, Lau E, Winkler JV. A novel assay for cobalt-albumin binding and its potential as a marker for myocardial ischemia-a preliminary report. J Emerg Med 2000;19:311-5. [CrossRef]

15. Punz A, Nanobashvili J, Neumayer C, Blumer R, Gassner R, Fuegl A, et al. Multivitamin administration before ischemia reduces ischemia-reperfusion injury in rabbit skeletal muscle. Clin Nutr 1999;18:219-26. [CrossRef]
16. Kılıç Y, Özer A, Tatar T, Zor MH, Kirişçi M, Kartal H, et al. Effect of picroside II on hind limb ischemia reperfusion injury in rats. Drug Des Devel Ther 2017;11:1917-25. [CrossRef]

17. Yonar ME. Protective effect of lycopene on oxidative stress and antioxidant status in Cyprinus carpio during cypermethrin exposure. Environ Toxicol 2013;28:609-16. [CrossRef]

18. Darwish SF, El-Bakly WM, Arafa HM, El-Demerdash E. Targeting TNF- $\alpha$ and NF-KB activation by bee venom: role in suppressing adjuvant induced arthritis and methotrexate hepatotoxicity in rats. PLoS One 2013;8:e79284. [CrossRef]

19. Kim H. Inhibitory mechanism of lycopene on cytokine expression in experimental pancreatitis. Ann N Y Acad Sci 2011;1229:99-102. [CrossRef]

20. Rousseau EJ, Davison AJ, Dunn B. Protection by beta-carotene and related compounds against oxygen-mediated cytotoxicity and genotoxicity: implications for carcinogenesis and anticarcinogenesis. Free Radic Biol Med 1992;13:407-33. [CrossRef]

21. Rao AV, Agarwal S. Role of lycopene as antioxidant carotenoid in the prevention of chronic diseases: a review. Nutrit Res 1999;19:305-23.

22. Marcotorchino J, Romier B, Gouranton E, Riollet C, Gleize B, Malezet-Desmoulins C, et al. Lycopene attenuates LPS-induced TNF- $\alpha$ secretion in macrophages and inflammatory markers in adipocytes exposed to macrophage-conditioned media. Mol Nutr Food Res 2012;56:725-32. [CrossRef]

23. Mellert W, Deckardt K, Gembardt C, Schulte S, Van Ravenzwaay B, Slesinski R. Thirteen-week oral toxicity study of synthetic lycopene products in rats. Food Chem Toxicol 2002;40:1581-8. [CrossRef]

24. Michael McClain R, Bausch J. Summary of safety studies conducted with synthetic lycopene. Regul Toxicol Pharmacol 2003;37:274-85. [CrossRef]

25. Buege JA, Aust SD. Microsomal lipid peroxidation. Methods Enzymol 1978;52:302-10. [CrossRef]

26. Beyer WF Jr, Fridovich I. Assaying for superoxide dismutase activity: some large consequences of minor changes in conditions. Anal Biochem 1987;161:559-66. [CrossRef]

27. Paglia DE, Valentine WN. Studies on the quantitative and qualitative characterization of erythrocyte glutathione peroxidase. J Lab Clin Med 1967;70:158-69.

28. Land WG. The role of postischemic reperfusion injury and other nonantigen-dependent inflammatory pathways in transplantation. Transplantation 2005;79:505-14. [CrossRef]

29. Le Moine O, Louis H, Stordeur P, Collet JM, Goldman M, Devière J. Role of reactive oxygen intermediates in interleukin 10 release after cold liver ischemia and reperfusion in mice. Gastroenterology 1997;113:1701-6.

30. Takhtfooladi HA, Takhtfooladi MA. Effect of curcumin on lung injury induced by skeletal muscle ischemia/reperfusion in rats. Ulus Travma Acil Cerrahi Derg 2019;25:7-11. [CrossRef]

31. Elmali N, Esenkaya I, Karadağ N, Taş F, Elmali N. Effects of resveratrol on skeletal muscle in ischemia-reperfusion injury. Ulus Travma Acil Cerrahi Derg 2007;13:274-80.

32. Ozyurt H, Ozyurt B, Koca K, Ozgocmen S. Caffeic acid phenethyl ester (CAPE) protects rat skeletal muscle against ischemia-reperfusion-induced oxidative stress. Vascul Pharmacol 2007;47:108-12. [CrossRef]

33. Koca K, Yurttaş Y, Yildız C, Caycı T, Uysal B, Korkmaz A. Effect of hyperbaric oxygen and ozone preconditioning on oxidative/nitrosative stress induced by tourniquet ischemia/reperfusion in rat skeletal muscle. Acta Orthop Traumatol Turc 2010;44:476-83. [CrossRef]

34. Kaya C, Karabulut R, Turkyilmaz Z, Sonmez K, Kulduk G, Gülbahar Ö, et al. Lycopene has reduced renal damage histopathologically and biochemically in experimental renal ischemia-reperfusion injury. Ren Fail 2015;37:1390-5. [CrossRef]

35. Hua Y, Xu N, Ma T, Liu Y, Xu H, Lu Y. Anti-Inflammatory Effect of Lycopene on Experimental Spinal Cord Ischemia Injury via Cyclooxygenase-2 Suppression. Neuroimmunomodulation 2019;26:84-92. 
36. Bansal P, Gupta SK, Ojha SK, Nandave M, Mittal R, Kumari S, et al. Cardioprotective effect of lycopene in the experimental model of myocardial ischemia-reperfusion injury. Mol Cell Biochem 2006;289:1-9.

37. Biswas SK. Does the Interdependence between Oxidative Stress and Inflammation Explain the Antioxidant Paradox?. Oxid Med Cell Longev 2016;2016:5698931. [CrossRef]

38. Dogukan A, Tuzcu M, Agca CA, Gencoglu H, Sahin N, Onderci M, et al. A tomato lycopene complex protects the kidney from cisplatin-induced injury via affecting oxidative stress as well as Bax, Bcl-2, and HSPs ex- pression. Nutr Cancer 2011;63:427-34. [CrossRef]

39. Ghavipour M, Saedisomeolia A, Djalali M, Sotoudeh G, Eshraghyan MR, Moghadam AM, et al. Tomato juice consumption reduces systemic inflammation in overweight and obese females. Br J Nutr 2013;109:2031-5. [CrossRef]

40. Davies MJ. Singlet oxygen-mediated damage to proteins and its consequences. Biochem Biophys Res Commun 2003;305:761-70. [CrossRef]

41. Conn PF, Schalch W, Truscott TG. The singlet oxygen and carotenoid interaction. J Photochem Photobiol B 1991;11:41-7. [CrossRef]

\section{DENEYSEL ÇALIŞMA - ÖZET}

\section{Sıçan arka uzuv kas modelinde iskemi/reperfüzyon hasarına yönelik likopenin koruyucu etkisi \\ Dr. Mehmet Kirişçi, ${ }^{1}$ Dr. Bülent Güneri, ${ }^{2}$ Dr. Muhammed Seyithanoğlu, ${ }^{3}$ Dr. Ülkü Kazancı, ${ }^{4}$ Dr. Adem Doğaner, ${ }^{5}$ Dr. Hakan Güneş ${ }^{6}$}

${ }^{1}$ Kahramanmaraş Sütçü İmam Üniversitesi Tip Fakültesi, Kalp Damar Cerrahi Anabilim Dalı, Kahramanmaraş

${ }^{2}$ Kahramanmaraş Sütçü İmam Üniversitesi Tip Fakültesi, Ortopedi ve Travmatoloji Anabilim Dalı, Kahramanmaraş

${ }^{3}$ Kahramanmaraş Sütçü İmam Üniversitesi Tip Fakültesi, Tibbi Biyokimya Anabilim Dalı, Kahramanmaras

${ }^{4}$ Kahramanmaraş Sütçü İmam Üniversitesi Tip Fakültesi, Tibbi Patoloji Anabilim Dalı, Kahramanmaraş

${ }_{5}^{5}$ Kahramanmaraş Sütçü İmam Üniversitesi Tip Fakültesi, Biyoistatistik ve Tibbi Bilişim Anabilim Dalı, Kahramanmaraș

${ }^{6}$ Kahramanmaraş Sütçü İmam Üniversitesi Tip Fakültesi, Kardiyoloji Anabilim Dalı, Kahramanmaraș

AMAÇ: Önemli bir mortalite ve morbidite sebebi olan iskelet kasının akut iskemi/reperfüzyon (I/R) hasarı oksidatif stres ile ilişkilidir. Etkin bir antioksidatif ve bir tür karotenoid pigment olan likopen meyve ve sebzelerde bulunmaktadır. Çalışmamız sıçan arka uzuv kas modelinde likopenin I/R hasarına karşı koruyucu etkisini incelemektedir.

GEREÇ VE YÖNTEM: Otuz iki adet Wistar-albino türü sıçan kontrol, likopen, I/R ve I/R+likopen gruplarına rasgele dağıtıldı. Likopen ve i// $R+$ likopen gruplarındaki sıçanlar deneyden önceki 15 gün boyunca ağızdan günde, $10 \mathrm{mg} / \mathrm{kg}$ miktarında likopen aldı. Tüm sıçanlara genel anestezi altında böbrek altı seviyesinde abdominal aorta diseksiyonu uygulandı. I/R ve I/R+likopen gruplarında aorta, böbrek altı seviyesinde iki saat süre ile klemp kullanılarak kapatıldı. Ardından bu gruplarda iki saat süre ile reperfüzyona olanak sağlandı. Feda edildikten sonra sıçanların arka uzuv kasından biyokimyasal ve histopatolojik inceleme için örnekler alındı.

BULGULAR: I/R+likopen grubunda serum ve doku malondialdehit ve iskemi modifiye albumin düzeyleri I/R grubuna kıyasla anlamlı derecede düşüktü $(\mathrm{p}<0.00 \mathrm{I})$. I/R grubunda serum glutatyon peroksidaz (GSH-Px) düzeylerinin kontrol ve I/R+likopen gruplarındakine göre anlamlı derecede düşük olduğu belirlendi $(p<0.05)$. I/R grubunda doku GSH-Px düzeyleri likopen grubundakine göre anlamlı derecede düşüktü $(p=0.003)$. Diğer üç gruba oranla I/R grubunda serum süperoksit dismutaz (SOD) düzeylerinin anlamlı derecede düşük olduğu saptandı $(p<0.00 I)$. I/R grubunda doku SOD seviyeleri kontrol ve likopen gruplarındakine göre anlamlı derecede düşüktü $(p=0.005)$. Histopatolojik incelemelerde $I / R+l i k o p e n$ grubunda I/R hasarına bağı enflamatuvar değişimlerin belirgin olarak az olduğu görüldü.

TARTIŞMA: Çalışmamız sıçan iskelet kası modelinde likopenin I/R hasarına karşı hücre koruyucu etkinliğini göstermektedir.

Anahtar sözcükler: Antioksidanlar; iskemi; likopen; reperfüzyon hasarı; turnike.

Ulus Travma Acil Cerrahi Derg 2020;26(3):35I-360 doi: I0.14744/tjtes.2020.8I456 